\title{
RISK ANALYSIS OF THE ECONOMIC VIABILITY OF FEEDLOT ABERDEEN ANGUS STEERS FED WITH DIFFERENT PROPORTIONS OF CONCENTRATE
}

\author{
ANÁLISE DE RISCO DA VIABILIDADE ECONÔMICA DO CONFINAMENTO DE \\ NOVILHOS ABERDEEN ANGUS ALIMENTADOS COM DIFERENTES \\ PROPORÇÕES DE CONCENTRADO
}

\section{Joilmaro Rodrigo Pereira ROSA ${ }^{1}$; Paulo Santana PACHECO² Edom de Avila FABRICIO $^{3}$; Angelina CAMERA; ${ }^{4}$ Daniel Batista LEMES $^{5}$}

1. Professor, Doutor, Universidade Federal de Santa Maria, Campus Frederico Westphalen, RS, Brasil; 2. Professor, Doutor, Universidade Federal de Santa Maria, Santa Maria, RS, Brasil. pacheco.dz.ufsm@ hotmail.com; 3. Doutorando em Zootecnia, Universidade Federal de Santa Maria, Santa Maria, RS, Brasil; 4. Graduanda em Zootecnia, Universidade Federal de Santa Maria, Santa Maria, RS, Brasil; 4. Mestrando em Zootecnia, Universidade Federal de Santa Maria, Santa Maria, RS, Brasil.

\begin{abstract}
The economic viability of feedlot Aberdeen Angus steers fed with diets composed of different concentrate levels (CL) in dry matter $(25,40,55$ or $70 \%)$ was estimated using Monte Carlo simulation combined with Spearman rank correlation, considering nine random input variables, as well as stochastic dominance (DOM) and sensitivity (SENS) analyses. For the financial indicator simulation, net present value (NPV), cash flow with indicators of performance, and the probability distribution of all cost and income items (from 2003 to 2014) were used. Latin hypercube sampling and a Mersenne Twister random number generator was employed for the simulation, which included 2000 interactions. The expected mean values \pm standard deviation for NPV (USD/animal) were $44.94 \pm 68.01,44.50 \pm 69.25$, $15.39 \pm 69.22$ and $54.20 \pm 71.58$ for the diets containing $25,40,55$ and $70 \%$ CL, respectively. The probability of NPV $\geq 0$ was 76.8, 76.0, 57.9 and 78.1\%, respectively, from the smallest to largest CL. The DOM analysis showed that 25 and $40 \%$ CL have similar probability curves, the $70 \%$ level dominated the remaining and all CL dominated 55\%. According to SENS analysis, the items that most influenced the NPV were, in decreasing order, finished and feeder cattle price, initial and final weights, concentrate and roughage price, concentrate intake, minimum rate of attractiveness and roughage intake. Based on the simulation results, the $70 \%$ CL showed a higher NPV and greater likelihood of economic viability. The probabilistic simulation technique is an interesting tool for decision-making in investment projects with beef cattle feedlot, therefore, further studies in this line of research is recommended.
\end{abstract} correlation

KEYWORDS: Investment analysis. Investment project. Probabilistic analysis. Stochastic method. Rank

\section{INTRODUCTION}

Beef cattle production systems in Brazil have been continuously intensified in recent years. As a result, feedlot operations are a technological alternative widely used by technicians and farmers. According to estimates by Anualpec (2015), approximately 4 million cattle $(10 \%$ of total cattle slaughtered) were feedlot-finished.

Among the technical factors involved in executing a feedlot operation, the diet of cattle is highly important due to its direct relation to performance aspects (weight gain, feed conversion and intake), economic viability (cost and revenue), and interactions between these factors. Various dietary concentrate levels have been evaluated in studies involving feedlot cattle due to operational and financial viability (PACHECO et al., 2006; MILLEN et al., 2009; MISSIO et al., 2009; LOPES et al., 2011; COSTA JUNIOR et al., 2013), however, the choice regarding the concentrate level is often empirical.

The Monte Carlo simulation technique, although routinely used in other areas of science, is not widely used for decision-making in animal production systems. However, recent studies have encouraged the use of this technique for similar applications (PACHECO et al., 2014 a, b). Monte Carlo simulations provide information related to several interpretations of statistical results (ALBRIGHT et al., 2010; PALISADE et al., 2010; PACHECO et al., 2014 a, b), used to assist decisionmaking for whether to invest or not. Thus, it is possible to not only determine the expected value of return on investment, but also estimate the risk involved.

Techniques such as stochastic dominance (DOM) and sensitivity (SENS) analyses are other options that complement the estimation and interpretation of investment risk. As the level of concentrate used in feedlot cattle diets in Brazil has increased (MILLEN et al., 2009; COSTA JUNIOR 
et al., 2013), considering that diet is an important contributor to production costs, the application of methodologies that help investors, technicians and producers to make decisions aimed at achieving greater likelihood of economic success has become highly relevant.

The aim of this study was to quantify the economic viability risk of feedlot Aberdeen Angus steers, fed with diets containing different levels of concentrate, using stochastic simulation techniques (Monte Carlo, stochastic dominance and sensitivity analyses).

\section{MATERIAL AND METHODS}

This study was conducted at the Animal Science Department of the Federal University of Santa Maria, in Santa Maria, located in the central depression of Rio Grande do Sul state (95 $\mathrm{m}$ above sea level), at $29^{\circ} 43^{\prime} \mathrm{S}$ and $53^{\circ} 42^{\prime} \mathrm{W}$ (DNPEA, 1973), where according to Köppen classification, the climate is humid subtropical (cfa) (MORENO, 1961).

Details of the experimental procedure during the feeding phase to obtain the animal performance indicators have been described previously by Rosa et al. (2006) for 16 Aberdeen Angus steers in contemporary groupings from the same herd. The animals were identified, vaccinated, treated against endo- and ectoparasites, then allocated into confinement facilities (individual boxes with a total area of $9 \mathrm{~m}^{2}$, each containing a concrete bowl for water fountains and individual wooden feeders) throughout a 30-day adaptation period. A slaughter weight of $450 \mathrm{~kg}$ was established for all treatments (obtained $463 \mathrm{~kg}$ ).

Feed management was set to provide daily at 08:00 and 14:00. Feed was supplied ad libitum, seeking to maintain a surplus of $10 \%$ of the offered food. The offered amount of roughage concentrate and the remains from the previous day were weighed and recorded daily in order to estimate dry matter (DM) intake.

We evaluated four concentrate levels in the diets $(25,40,55$ and $70 \%$ of DM). The experimental design was completely randomized, consisting of four treatment groups with four replicates in each.

The roughage used was corn silage (Zea mays L.) AG-5011 hybrid, which provided $38.5 \%$ DM and $7.3 \%$ crude protein. The diet of the animals was modified so that crude protein (CP; isoprotein) made up $13.4 \%$ for all treatments, assuming an average daily consumption of $2.5 \%$ of body weight and average daily weight gain of $1.4 \mathrm{~kg} / \mathrm{animal}$ (NRC, 1996). The amount of roughage concentrate supplied differed between treatment groups. The proportion of ingredients in the concentrate, and the performance characteristics of the animals are shown in Table 1.

Table 1. Diets composition, express in dry matter (DM) and performance indicators according to concentrate level

\begin{tabular}{|c|c|c|c|c|}
\hline Concentrate level, \% DM & 25 & 40 & 55 & 70 \\
\hline Cor ground grain $(\mathrm{kg})$ & 20.00 & 40.00 & 49.60 & 55.00 \\
\hline Wheat bran (kg) & 10.00 & 20.00 & 24.80 & 27.50 \\
\hline Soybean meal (kg) & 66.40 & 37.10 & 23.45 & 15.71 \\
\hline Limestone $(\mathrm{kg})$ & 1.20 & 1.15 & 0.91 & 1.00 \\
\hline Salt $(\mathrm{NaCl})(\mathrm{kg})$ & 2.40 & 1.75 & 1.24 & 0.79 \\
\hline Ionophore (Rumensin $®)(g)$ & 75.00 & 46.90 & 34.10 & 26.80 \\
\hline Feeding time (days) & 112 & 100 & 100 & 84 \\
\hline Initial weight (kg) & 336 & 335 & 340 & 327 \\
\hline Final weight (kg) & 475 & 462 & 460 & 454 \\
\hline Total weight gain (kg) & 139 & 127 & 120 & 127 \\
\hline Daily dry matter intake $(\mathrm{kg})$ & 8.7 & 9.3 & 9.8 & 10.8 \\
\hline Hot carcass weight $(\mathrm{kg})$ & 250 & 248 & 252 & 256 \\
\hline Subcutaneous fat thickeness (mm) & 7.8 & 6.6 & 6.5 & 7.3 \\
\hline
\end{tabular}

Source: Adapted from ROSA (2006).

The methodology described by Pacheco et al. (2014b) was used for the estimates of production costs. The items related to cost (purchase of feeder cattle, roughage and concentrate feed, manual labor, health, depreciation and other operational expenses) and income (finished cattle) were associated with the performance characteristics obtained during the feeding period (initial and final weights, average daily weight gain and daily DM intake). The items used to comprise the costs and revenue were derived from quotes obtained for 12 consecutive years (between 2003 and 2014). 
The facility costs were estimated for a static capacity of 1000 animals with a lifespan of 10 years. Details of the calculations of depreciation, sanitary control, feed cost, manual labor cost and other operating expenses have been previously described by Pacheco et al. (2014b).

The net present value (NPV; USD/animal) was used as a financial indicator, calculated by the equation $\sum_{i=1}^{\mathrm{n}} \frac{\text { valus }_{i}}{(1+\text { rass })^{i}}$, where $n$ is the number of months, $i$ is the $\mathrm{n}^{\text {th }}$ time period in which money is invested in the project, rate is the minimum rate of investment attractiveness and values represent the net revenue. The cash flow for each concentrate level considered separate investment projects with a planning horizon time of one year, using the Spearman correlation to determine associations between input variables.

The NPV simulations used the cash flow, including probability distributions of all items of cost and revenue, as well as livestock indicators.
Latin hypercube sampling and a Mersenne Twister random number generator with 2000 repetitions were employed for the simulation (PACHECO et al., 2014b).

All estimates were made per animal per year, deflated for the year 2014 by the general price index (internal availability calculated by the Getúlio Vargas Foundation). For the purposes of currency conversion, $\mathrm{R} \$ 1.00$ was considered to be equal to USD 0.40 .

Microsoft ${ }^{\circledR}$ Excel (Redmond, WA, USA), $@$ @isk ${ }^{\circledR}$ (Ithaca, NY, USA) and SAS ${ }^{\circledR}$ Studio (Cary, NC, USA) software were used to perform the risk assessments, following the methods described by Albright et al. (2010) and Pacheco et al. (2014b).

Definitions of probability distribution (considering Anderson-Darling test) for the cost, revenue and technology characterization items, and Spearman correlations between the random input variables, are presented in Tables 2,3 and 4.

Table 2. Probability distributions for the items of performance, costs and revenue.

\begin{tabular}{lclccl}
\hline Item $^{\text {I }}$ & $\begin{array}{r}\text { Conc. } \\
\text { level }\end{array}$ & Distributions (parameters) & Item & $\begin{array}{r}\text { Conc. } \\
\text { level }\end{array}$ & Distributions (parameters) \\
\hline 1 & All & Weibull $(2.2329 ; 1.2997)$ & & 25 & Triangular $(302.4 ; 336 ; 369.6)$ \\
2 & All & Logistic $(3.59756 ; 0.28183)$ & & 40 & Triangular $(301.5 ; 335 ; 368.5)$ \\
3 & All & Logistic $(0.317781 ; 0.022828)$ & 8 & 55 & Triangular $(306 ; 340 ; 374)$ \\
& 25 & Uniform $(0.82344 ; 1.35134)$ & & 70 & Triangular $(294.3 ; 327 ; 359.7)$ \\
4 & 40 & ExtvalueMin $(0.90874 ; 0.080317)$ & & 25 & Triangular $(427.5 ; 475 ; 552.5)$ \\
& 55 & Weibull $(5.5506 ; 0.37321)$ & & 40 & Triangular $(415.8 ; 462 ; 508.2)$ \\
& 70 & Logistic $(0.694056 ; 0.037194)$ & 9 & 55 & Triangular $(414 ; 460 ; 506)$ \\
& 25 & Triangular $(5.877 ; 6.53 ; 7.183)$ & & 70 & Triangular $(408.6 ; 454 ; 499.4)$ \\
5 & 40 & Triangular $(5.058 ; 5.62 ; 6.182)$ & 10 & All & ExtvalueMin $(639.1459 ; 81.007)$ \\
& 55 & Triangular $(3.969 ; 4.41 ; 4.851)$ & 11 & All & Loglogistic $(3818.4 ; 4673 ; 3.1441)$ \\
& 70 & Triangular $(2.907 ; 3.23 ; 3.553)$ & 12 & All & Uniform $(0.036241 ; 0.056843)$ \\
& 25 & Triangular $(1.962 ; 2.18 ; 2.398)$ & 13 & All & Uniform $(0.016205 ; 0.064772)$ \\
6 & 40 & Triangular $(3.375 ; 3.75 ; 4.12)$ & 14 & All & ExtvalueMin $(5.1128 ; 1.3023)$ \\
& 55 & Triangular $(4.85 ; 5.39 ; 5.929)$ & 15 & All & Normal $(0.87 ; 0.0087)$ \\
& 70 & Triangular $(6.786 ; 7.54 ; 8.294)$ & & & \\
& 25 & Triangular $(1.116 ; 1.24 ; 1.364)$ & & & \\
7 & 40 & Triangular $(1.143 ; 1.27 ; 1.397)$ & & & \\
& 55 & Triangular $(1.08 ; 1.20 ; 1.32)$ & & & \\
& 70 & Triangular $(1.359 ; 1.51 ; 1.661)$ & & &
\end{tabular}

${ }^{1} 1$ Feeder steer (USD/@); 2 Finished steer (USD/@); 3 Roughage (USD/kg DM); 4 Concentrate (USD/kg DM); 5 Roughage intake (kg DM/animal/day); 6 Concentrate intake (kg DM/animal/day); 7 Average weight gain (kg/animal/day); 8 Initial weight (kg); 9 Final weight (kg); 10 Wage (USD); 11 Land (USD); 12 Depreciation of facilities and equipments (USD/animal/day); 13 Depreciation of machinery and implements (USD/animal/day); 14 Health (USD/animal); 15 Minimum rate of attractiveness (\% a.m).

${ }^{2}$ Weibull (alpha; beta); Logistic (alpha; beta); Uniform (minimum; maximum); ExtvalueMin (alpha; beta); Triangular (minimum; most likely; maximum); Loglogistic (gama; beta; alpha); Normal (mean; standard deviation) 
For the simulation of NPV, the Monte Carlo method was used with Latin hypercube sampling (MCKAY et al., 1979; IMAN et al., 1981) and a Mersenne Twister random number generator (MATSUMOTO; NISHIMURA, 1998) with 2000 iterations. From this simulation, the probabilities for occurrence of NPVs were estimated above zero, specifically the probability of economic viability (MOORE; WEATHERFORD, 2001).

Table 3. Spearman correlation coefficients of the cost and revenue items to $25 \%$ (below diagonal) and $40 \%$ (above diagonal) concentrate level in percentage of dry matter.

\begin{tabular}{lccccccccc}
\hline \multicolumn{1}{c}{ Items } & 1 & 2 & 3 & 4 & 5 & 6 & 7 & 8 & 9 \\
\hline 1 Feeder steer (USD/kg) & & 0.85 & 0.85 & 0.65 & -0.76 & 0.13 & -0.83 & -0.82 & -0.61 \\
2 Finished steer (USD/kg) & 0.86 & & 0.76 & 0.68 & -0.66 & 0.09 & -0.75 & -0.77 & -0.41 \\
3 Wage (USD/month) & 0.88 & 0.76 & & 0.76 & -0.93 & -0.13 & -0.96 & -0.96 & -0.79 \\
4 Land (USD/ha) & 0.72 & 0.68 & 0.76 & & -0.80 & 0.10 & -0.82 & -0.86 & -0.54 \\
5 Roughage (USD/kg DM) & -0.80 & -0.66 & -0.93 & -0.80 & & 0.24 & 0.95 & 0.94 & 0.73 \\
6 Concentrate (USD/kg DM) & 0.20 & 0.16 & -0.03 & 0.18 & 0.19 & & 0.09 & -0.02 & 0.18 \\
7 Facilities/equipments (USD/animal/day) & -0.87 & -0.75 & -0.96 & -0.82 & 0.95 & 0.03 & & 0.98 & 0.82 \\
8 Machinery/implements (USD/animal/day) & -0.87 & -0.77 & -0.96 & -0.86 & 0.94 & -0.09 & 0.98 & & 0.74 \\
9 Health (USD/animal) & -0.65 & -0.41 & -0.79 & -0.54 & 0.73 & 0.12 & 0.82 & 0.74 & \\
\hline
\end{tabular}

Table 4. Spearman correlation coefficients of the cost and revenue items to 55\% (below diagonal) and $70 \%$ (above diagonal) concentrate level in percentage of dry matter.

\begin{tabular}{lccccccccc}
\hline \multicolumn{1}{c}{ Items } & 1 & 2 & 3 & 4 & 5 & 6 & 7 & 8 & 9 \\
\hline 1 Feeder steer (USD/kg) & & 0.85 & 0.85 & 0.65 & -0.76 & 0.06 & -0.83 & -0.82 & -0.61 \\
2 Finished steer (USD/kg) & 0.85 & & 0.76 & 0.68 & -0.66 & -0.02 & -0.75 & -0.77 & -0.41 \\
3 Wage (USD/month) & 0.85 & 0.76 & & 0.76 & -0.93 & -0.27 & -0.96 & -0.96 & -0.79 \\
4 Land (USD/ha) & 0.65 & 0.68 & 0.76 & & -0.80 & -0.03 & -0.82 & -0.86 & -0.54 \\
5 Roughage (USD/kg DM) & -0.76 & -0.66 & -0.93 & -0.80 & & 0.30 & 0.95 & 0.94 & 0.73 \\
6 Concentrate (USD/kg DM) & 0.09 & 0.03 & -0.21 & 0.03 & 0.28 & & 0.17 & 0.09 & 0.24 \\
7 Facilities/equipments (USD/animal/day) & -0.83 & -0.75 & -0.96 & -0.82 & 0.95 & 0.14 & & 0.98 & 0.82 \\
8 Machinery/implements (USD/animal/day) & -0.82 & -0.77 & -0.96 & -0.86 & 0.94 & 0.04 & 0.98 & & 0.74 \\
9 Health (USD/animal) & -0.61 & -0.41 & -0.79 & -0.54 & 0.73 & 0.22 & 0.82 & 0.74 & \\
\hline
\end{tabular}

In order to evaluate stochastic dominance, pairs of cumulative probability distributions of simulated NPVs for different concentrate levels were compared according to first- and second-order criteria (HADAR; RUSSEL, 1969; HANOCH; LEVY, 1969). Significant differences were identified using an asymptotic KolmogorovSmirnov test (CONOVER, 1999).

For the sensitivity analysis, multivariate stepwise regression with standardized regression coefficients were used (ALBRIGHT et al., 2010; PALISADE, 2010). The standardized multivariate regression coefficient indicates the number of standard deviations of the NPV that will change with each change of one standard deviation in the input variables, assuming that all the other input variables remain constant (ALBRIGHT et al., 2010).

\section{RESULTS}

The results related to simulation of the financial indicator NPV (Table 5) demonstrates feasibility for all levels of concentrate used. However, considering the expected mean values, the lowest viability was observed for the $55 \%$ concentrate level (USD 15.39/animal), while the $70 \%$ level achieved the best results (USD 54.20/animal).

The other statistics, presented in Table 5, are related to the variability of the simulated values in relation to the average estimated, allowing quantification of the risk associated with investment. Greater risk is associated with higher values for the minimum, maximum, standard deviation and coefficient of variation, as there are 
greater chances for obtaining values different to that

expected average.

Table 5. Net Present Value (NPV) statistics (USD/animal), simulated with correlation between input variables, according to concentrate level.

\begin{tabular}{lcccc}
\hline Concentrate level, \% DM & 25 & 40 & 55 & 70 \\
\hline Minimum & -313.49 & -348.24 & -306.00 & -254.64 \\
Maximum & 285.83 & 432.81 & 269.94 & 379.45 \\
Mean & 44.94 & 44.50 & 15.39 & 54.20 \\
Standard deviation & 68.01 & 69.25 & 69.22 & 71.58 \\
Coefficient of variation (\%) & 151.33 & 155.63 & 449.77 & 132.08 \\
NPV $\geq 0$ & $76.8 \%$ & $76.0 \%$ & $57.9 \%$ & $78.1 \%$ \\
\hline
\end{tabular}

The analysis related to the risk of the project showed the greatest standard deviation. In the present study, there was a high degree of similarity between this statistic and different levels of concentrate, ranging from USD 68.01 to 71.58 per animal. However, discrepancies among the results were found for the probability estimations of NPV $\geq$ 0 , which was less for the $55 \%$ concentrate level (57.9\%) and slightly higher for the $70 \%$ level (78.1\%) compared to 25 and $40 \%$ (76.8 and $76.0 \%$, respectively).
Figure 1 presents a graphical representation of the cumulative probability distribution of 2000 simulated values for the NPV for each concentrate level. This plot presents the NPV (X-axis) in terms of the cumulative probability (Y-axis), allowing visualization of the changes in NPV. One of the scenarios with higher expectation of being quantified is the percentage values above zero, i.e. the probability for profit or economic loss, taking into account the quantity of simulated values below zero

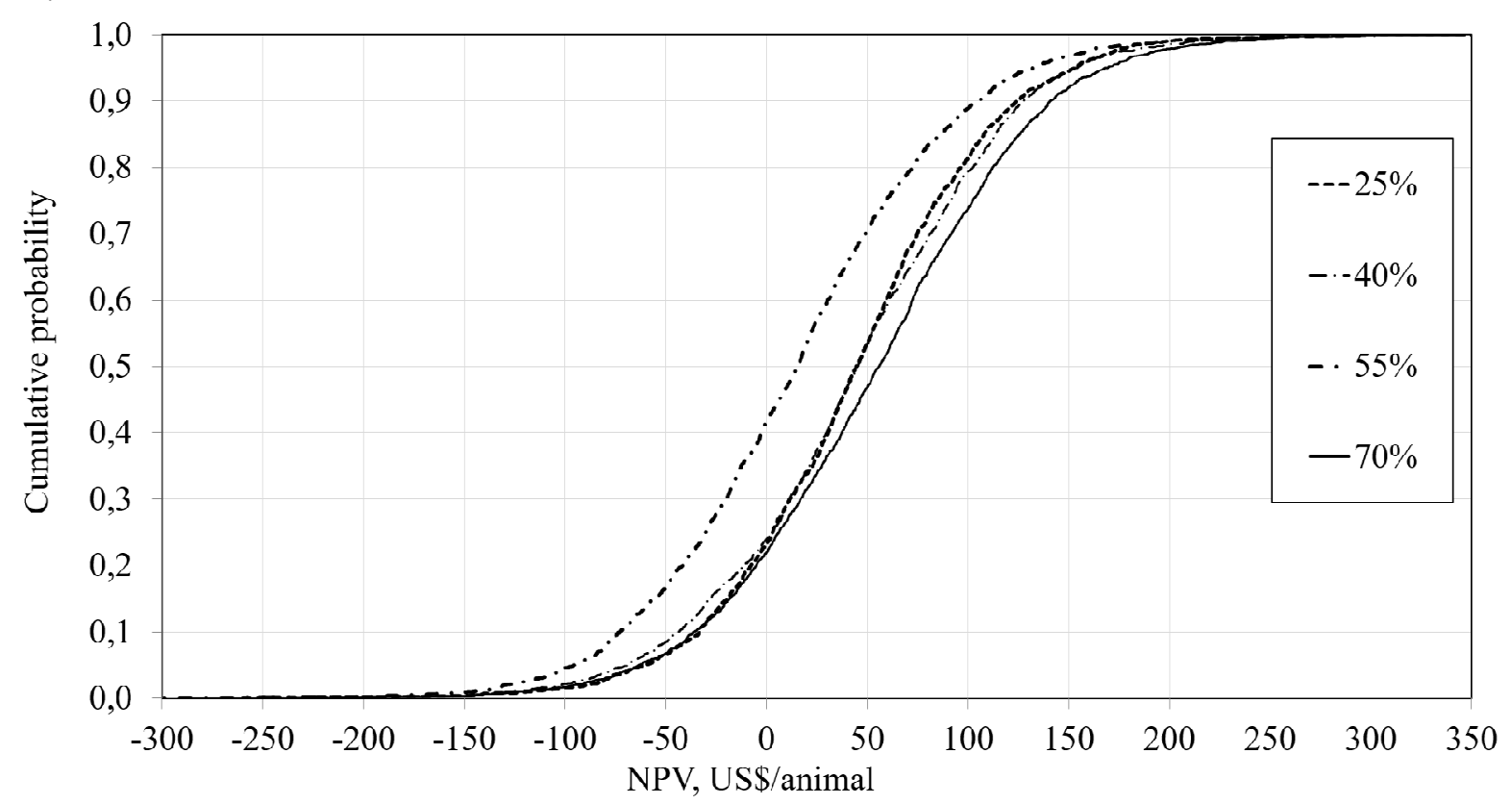

Figure 1. Distribution of cumulative probability in the simulation of Net Present Value (NPV) with correlation between the input variables according to concentrate level (DM basis)

Moreover, the stochastic dominance behavior between the levels of concentrate evaluated is evident in Figure 1. When the cumulative probability curves intersected one or more times, this was characterized as second-order stochastic dominance (investments selected by investors who prefer a higher return and are averse to high risk). All other cases were classified as first- order stochastic dominance (investments selected by investors who prefer a higher return). The leftmost curve in Figure 1 represents the 55\% concentrate level, whereas the rightmost was the $70 \%$ level, which showed the lowest and highest average NPV and NPV $\geq 0$, respectively.

To evaluate the potential statistical differences between the cumulative probability 
curves for the different levels of concentrate, they were subjected to a stochastic dominance test (Table $6)$. When the the distributions were individually compared ( 25 vs. $40 \%, 25$ vs. $55 \%, 55$ vs. $70 \%$ of concentrate), a significant difference $(\mathrm{P}=0.0885)$ was observed only for 25 vs. $40 \%$ levels (NPVs were statistically similar) according to the Kolmogorov-Smirnov asymptotic test.

Table 6. Stochastic dominance and domain type, according to the Kolmogorov-Smirnov asymptotic test (KSa) in comparison of pairs of probability distributions of concentrate levels (DM basis), with correlation between the input variables for the simulated Net Present Value.

\begin{tabular}{lcccc}
\hline Concentrate level pairs & KSa statistic & Pr $>$ KSa & Domain $^{1}$ & Type of dominance $^{2}$ \\
\hline 25 vs 40 & 1.25 & 0.0885 & - & - \\
25 vs 55 & 6.57 & $<0.0001$ & F & $>$ \\
25 vs 70 & 3.05 & $<0.0001$ & S & $>$ \\
40 vs 55 & 6.29 & $<0.0001$ & F & $<$ \\
40 vs 70 & 2.32 & $<0.0001$ & F & $<$ \\
55 vs 70 & 7.70 & $<0.0001$ & F &
\end{tabular}

${ }^{1}$ F: first order stochastic dominance; S: second order stochastic dominance; ${ }^{2}>$ : first concentrate level dominates the second concentrate level; <: second concentrate level dominates the first concentrate level.

Other comparisons between pairs of distributions showed first-order stochastic dominance for 25 vs. $55 \%, 40$ vs. $55 \%, 40$ vs. $70 \%$ and 55 vs. $70 \%$. Only the 25 vs. $70 \%$ comparison presented second-order dominance. Regarding the type of domain, the $55 \%$ concentrate level was dominated by levels 25 and $40 \%$, while the $70 \%$ level was dominated by 25,40 and $55 \%$.

The final method of risk analysis presented in this study was the sensitivity analysis using standardized regression coefficients (Figure 2). The tornado chart demonstrated that the most important items influencing the NPV financial indicator were, in descending order, price of finished cattle, price of feeder cattle, final weight, initial weight, concentrate price, roughage price, concentrate intake, rate of discount, and the roughage intake. Other items that constituted the inputs for probability distribution were found to have no influence (machinery, implements, cost of facilities and equipment, and animal health).

Considering the variability in standardized regression coefficients between the concentrate levels for each item, the four most highly-ranked items appeared to be slightly more important for the $25 \%$ concentrate level compared to the other levels tested. Regarding the items related to diet, it appears that higher concentrate levels were associated with decreased regression coefficients for roughage price and roughage intake, with the opposite behavior observed for concentrate price and concentrate intake.

It should be noted that the only items with positive coefficients were determinants of revenue (finished cattle price and final weight), with all other items, determining the total cost, showing negative coefficients. 
Risk analysis...

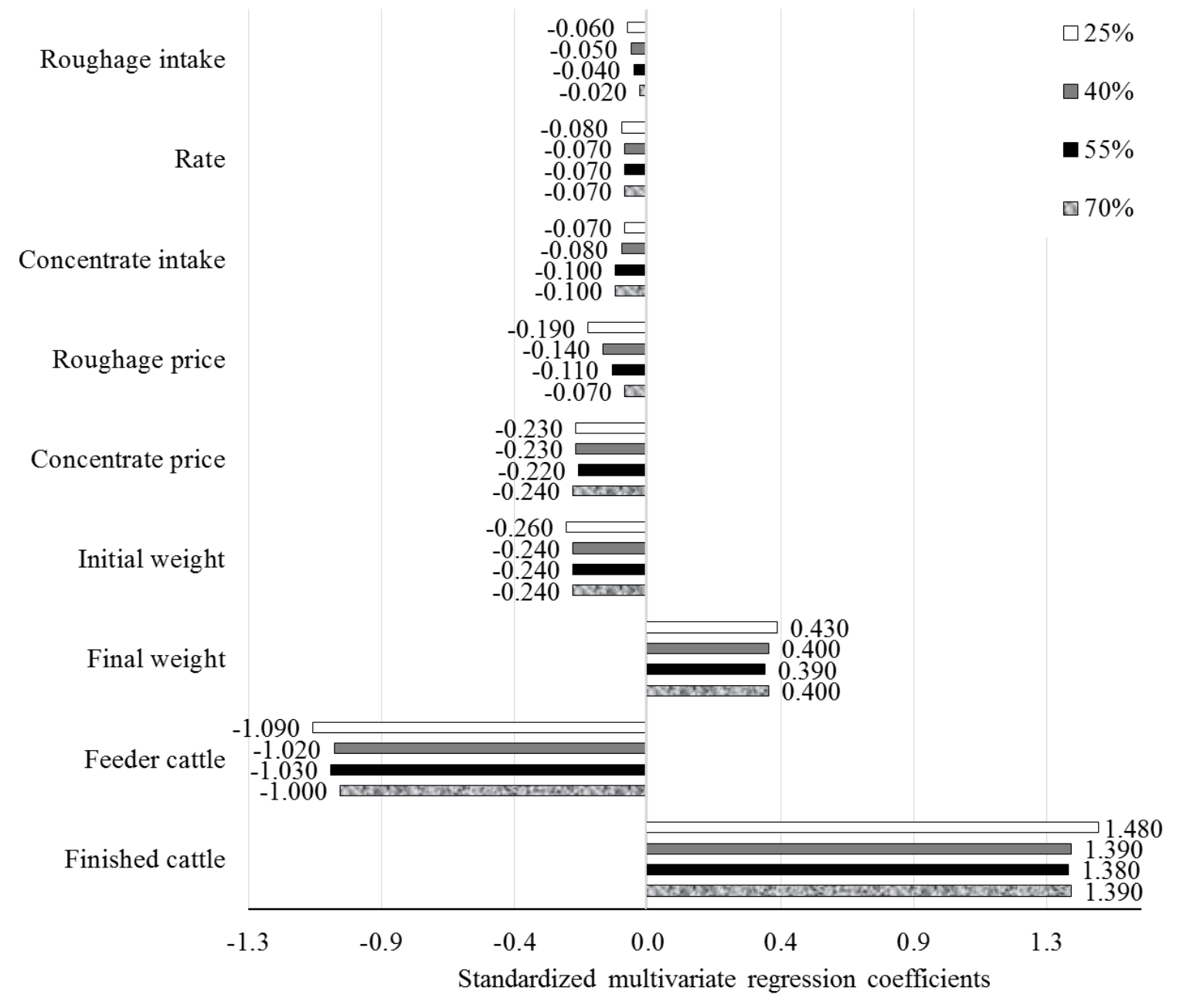

Figure 2. Standardized multivariate regression coefficients of the variables of greater relevance to the Net Present Value simulated, with correlation between the input variables, according to concentrate level (DM basis).

\section{DISCUSSION}

The statistics for NPV presented in Table 5 show favorable results in terms of economic viability, especially when higher levels of concentrate were used in the diet $(70 \%)$. In contrast, a previous study by Missio et al. (2009) observed negative economic viability when a $79 \%$ concentrate level was used, compared to 22, 40 and $59 \%$ DM. This comparison demonstrates the interaction between biological and economic responses, which is not always a linear relationship.

This study further justifies the use of economic analysis methodologies for animal production systems, especially investment projects that require high initial investments prior to implementation, such as cattle feedlot. In this respect, Monte Carlo simulation is a valuable technique. The use of Monte Carlo and stochastic simulations have been well-documented, however, they are predominantly used in other areas of science (TOURAN; WISER, 1992; WALL, 1997; YANG, 2005; ALBRIGHT et al., 2010).

The $70 \%$ concentrate level showed the highest probability of economic viability compared to the other levels evaluated. This favorable result was confirmed by analysis of stochastic dominance, which demonstrated that this level of concentrate resulted in higher returns and lower risk (secondorder stochastic dominance; Table 6). This information is of high importance, as according to Pacheco et al. (2006), excluding the purchasing cost of the feeder cattle, food represents the greatest contributor to total cost, for which the concentrate is the most expensive item.

There have been significant changes in the use of forage in Brazil, particularly the concentrate ratio of diets provided to feedlot cattle. Surveys 
performed by Millen et al. (2009) and Costa Junior et al. (2013) describe the nutritional aspects of concentrate use and its evolution. The concentrate levels used in Brazilian feedlots are high, usually greater than 80\% DM (MILLEN et al., 2009; COSTA JUNIOR et al., 2013), derived from that used for US feedlots (VASCONCELOS et al., 2007).

The literature regarding the application of stochastic simulation techniques in the production of beef cattle is limited, particularly for estimates of risk, stochastic dominance and probabilistic sensitivity analysis. Pacheco et al. (2014b) evaluated two slaughter ages (15.2 or 22.8 months) of feedlot steers (Charolais $\times$ Nellore), confirming that younger animals were associated with greater economic viability (R\$ 100.22 and 41.86, respectively) and higher NPV $\geq 0$ (80.4 and 62.3\%, respectively), considering 7 consecutive years of quotations (from 2004 to 2010; considering $\mathrm{R} \$ 1.00$ equal to USD 0.54).

The sensitivity analysis allows the items representing components of costs and revenues to be ranked for their influence on the financial measure in question, which was the output variable NPV in the current study. From Figure 2, it appears that there was marked stratification in the evaluated items. The first of the strata contained the items related to the feeder and finished cattle prices, which had the greatest influence on NPV. The second was represented by animal weight, and the third strata consisted of items related to diet, which showed little variation between the different levels of concentrate.

The information obtained from diet-related items can be used in management decisions, such as setting the best grain acquisition strategies and dietary ingredients, and monitoring volatility in the price of major grains, among other strategies, in order to obtain the best results for economic viability, as described by Lopes et al. (2011).

In a study that used probabilistic sensitivity analysis to evaluate the effect of different slaughter weights $(421,461$ and $495 \mathrm{~kg}$ ) on the economic viability of feedlot steers, Pacheco et al. (2014a) found similar results to those of the present study, that is, higher standardized regression coefficients for the price of finished cattle (ranging from 0.54 to 0.61 ) and feeder cattle (ranging from -0.43 to -0.56 ) as the most important items influencing NPV, followed by the price of roughage (ranging from 0.35 to -0.45 ) and concentrate (ranging from -0.29 to -0.33). In another study by Pacheco et al. (2014b) which assessed the effect of a reduction in the age of feedlot steers at slaughter, the regression coefficients ranged from 1:14 to 1:58 for finished cattle, from -1.12 to -1.53 for feeder cattle, 0.48 to 0.70 for final weight, -0.38 to -0.60 for initial weight, -0.14 to -0.07 for roughage price, and -0.24 to -0.05 for concentrate price.

\section{CONCLUSIONS}

Based on the results of this simulation analysis, the $70 \%$ concentrate level showed the best result for economic viability. The 55\% concentrate level showed the worst result, whereas 25 and $40 \%$ were similar, ranking between the other concentrate levels.

The items that had the greatest influence on net present value were, in decreasing order, finished and feeder cattle price, initial and final weights, concentrate and roughage price, concentrate intake, minimum rate of attractiveness and roughage intake.

RESUMO: Estimou-se o risco da viabilidade econômica do confinamento de novilhos Aberdeen Angus alimentados com dietas com diferentes níveis de concentrado (NC) na matéria seca (25, 40, 55 ou $70 \%$ ), utilizando simulação de Monte Carlo associado com o uso de correlação de Spearman entre nove variáveis aleatórias de entrada, dominância estocástica (DOM) e análise de sensibilidade (SENS). Para a simulação do indicador financeiro Valor Presente Líquido (VPL), foi utilizado fluxo de caixa com indicadores de desempenho e distribuição de probabilidade de todos os itens de custos e receitas (anos de 2003 a 2014). Amostragem de Hipercubo Latino e gerador de números aleatórios Mersenne Twister foram utilizados para a simulação com 2.000 interações. Os valores médios esperados para VPL \pm desvio padrão (USD/animal) foram de: 44,94 $\pm 68,01 ; 44,50 \pm 69,25 ; 15,39 \pm 69,22$ e 54,20 \pm 71,58, respectivamente, para 25, 40, 55 e 70\% NC. As probabilidades do VPL $\geq 0$ foram 76,8\%; 76,0\%; 57,9\% e 78,1\%, respectivamente, do menor para maior NC. A análise de DOM demonstrou que 25 e $40 \%$ de concentrado apresentam curvas de probabilidade similares; $70 \%$ dominou os demais e $55 \%$ foi dominado por todos os NC. De acordo com a SENS, os itens que mais influenciaram no VPL foram, em ordem decrescente, os preços do boi gordo e magro, os pesos final e inicial, preços do concentrado e do volumoso, consumo de concentrado, taxa mínima de atratividade e consumo de volumoso. Com base nos resultados de simulação, o NC de 70\% apresentou maior VPL e maior probabilidade de viabilidade econômica. A técnica de simulação probabilística demonstrou ser interessante ferramenta para tomada de decisões em projetos de investimento com confinamento de bovinos de corte, sugerindo a expansão de estudos nesta linha de pesquisa. 
PALAVRAS-CHAVE: Análise de investimento. Projeto de investimento. Análise probabilística. Método estocástico. Correlação de rank

\section{REFERENCES}

ALBRIGHT, S. C; WINSTON, W. L.; ZAPPE, C. J. Data analysis and decision making. Mason: SouthWestern Cengage Learning, ed. 4, 1080 p., 2010.

ANUALPEC. Anualpec 2015: anuário da pecuária brasileira. São Paulo: Informa Economics FNP, 2015. 280 p.

CONOVER, W. J. Practical nonparametric statistics. 3. ed. New York: John Wiley and Sons, 1999. 592 p.

COSTA JUNIOR, C; GOULART, R. S.; ALBERTINI, T. Z.; FEIGL, B. J.; CERRI, C. E. P.; VASCONCELOS, J. T.; BERNOUX, M.; LANNA, D. P. D.; CERRI, C. C. Brazilian beef cattle feedlot manure management: a country survey. J Anim Sci, Champain, v. 91, n. 4, p. 1811-1818, 2013.

DNPEA - Ministério da Agricultura: Departamento Regional de Pesquisa Agropecuária. Divisão de Pesquisas Pedológicas. Levantantamento de reconhecimento de solos do Rio Grande do Sul. Embrapa Solos, Recife, v. 30, 1973. 431p.

HADAR, J.; RUSSELL, W. R. Rules for ordering uncertain prospects. Am Econ Rev, Pittsburgh, v. 59, p. 25 34, 1969.

HANOCH, J.; LEVY, H. The efficiency analysis of choices involving risk. Am Econ Rev, Pittsburgh, v. 74, p. 335-346, 1969. https://doi.org/10.2307/2296431

IMAN, R. L.; HELTON, J. C.; CAMPBELL, J. E. An approach to sensitivity analysis of computer models, Part 1. Introduction, input variable selection and preliminary variable assessment. J Qual Tech, Milwaukee, v. 13, n. 3, p. 174-183, 1981.

LOPES, L. S.; LADEIRA, M. M.; MACHADO NETO, O. R.; SILVEIRA, A. R. M. C.; REIS, R. P.; CAMPOS, F. R. Viabilidade econômica da terminação de novilhos nelore e red norte em confinamento na região de Lavras-MG. Rev Cien Agro, Lavras, v. 35, n. 4, p. 774-780, 2011.

MATSUMOTO, M.; NISHIMURA, T. Mersenne twister: a 623-dimensionally equidistributed uniform pseudorandom number generator. ACM T Model Comput S, New York, v. 8, n. 1, p. 3-30, 1998.

MCKAY, M. D.; BECKMAN, R. J.; CONOVER, W. J. A Comparison of three methods for selecting values of input variables in the analysis of output from a computer code. J Am Stat Assoc, Alexandria, v. 21, n. 2, p. 239-245, 1979. https://doi.org/10.1080/00401706.1979.10489755 https://doi.org/10.2307/1268522

MILLEN, D. D.; PACHECO, R. D. L.; ARRIGONI, M. D. B.; GALYEAN, M. L.; VASCONCELOS, J. T. A snapshot of management practices and nutritional recommendations used by feedlot nutritionists in Brazil. J Anim Sci, Champain, v. 87, p. 3427-3439, 2009.

MISSIO, R. L.; BRONDANI, I. L.; FREITAS, L. S.; SACHET, R. H.; SILVA, J. H. S.; RESTLE, J. Desempenho e avaliação econômica da terminação de tourinhos em confinamento alimentados com diferentes níveis de concentrado na dieta. Rev Bras Zoot, Brasília, v. 38, p. 1309-1316, 2009.

https://doi.org/10.1590/S1516-35982009000700021 
MOORE, J. H.; WEATHERFORD, L. R. Decision Modeling with Microsoft Excel. Upper Saddle River: Prentice Hall, 2001. 704 p.

MORENO, J. A. Clima do Rio Grande do Sul. Porto Alegre: Secretaria da Agricultura, 1961. 41p.

NATIONAL RESEARCH COUNCIL - NRC. Nutrient requeriment of beef cattle. Washington D.C.: National Academy Press, 1996. 244 p.

PACHECO, P. S.; RESTLE, J.; OLEGARIO, J. L.; MENEZES, F. R.; VAZ, F. N.; PASCOAL, L. L.; LEMES, D. B.; VALENÇA, K. G.; MACHADO, G. I. O.; RODRIGUES, A. C. T. Correlation and slaughter weight on sensitivity analysis of charolais steers feedlot finished. AIJCR, New York, v. 4, p. 28-34, 2014a.

PACHECO, P. S.; RESTLE, J.; PASCOAL, L. L.; VAZ, F. N.; VAZ, R. Z.; VALENCA, K. G.; OLEGARIO, J. L. Use of correlation between input variables in estimating the risk of feedlot finishing of steers and young steers. An Acad Bras Cien, Rio de Janeiro, v. 86, p. 945-954, 2014 b.

PACHECO, P. S.; RESTLE, J.; VAZ, F. N.; FREITAS, A. K.; PADUA, J. T.; NEUMANN, M.; ARBOITTE; M. Z. Avaliação econômica da terminação em confinamento de novilhos jovens e superjovens de diferentes grupos genéticos. Rev Bras Zoot, Brasília, v. 35, n. 1, p. 309-320, 2006. https://doi.org/10.1590/S151635982006000100039

PALISADE. @ RISK: Risk analysis and simulation add-in for Microsoft ${ }^{\circledR}$ Excel. Ithaca: Palisade, 2010. $739 \mathrm{p}$.

ROSA, J. R. P. Exigências energéticas e protéicas de novilhos aberdeen angus submetidos ou não ao ganho compensatório. 2006. 149p. Tese (Doutorado em Zootecnia) - Curso de Pós-Graduação em Zootecnia, Universidade Federal do Rio Grande do Sul, Porto Alegre, 2006.

TOURAN, A.; WISER, E. P. Monte Carlo technique with correlated random variables. J Const Eng M Asce, New York, v. 118, p. 258-272, 1992.

VASCONCELOS, J. T.; GALYEAN, M. L. Nutritional recommendations of feedlot consulting nutritionists: The 2007 Texas Tech University survey. J Anim Sci, v. 85, p. 2772-2781, 2007.

https://doi.org/10.2527/jas.2007-0261

WALL, D. M. Distributions and correlations in Monte Carlo simulation. Constr Manage Econ, Grand Forks, v. 15, p. 241-258, 1997. https://doi.org/10.1080/014461997372980

YANG, I.-T. Simulation-based estimation for correlated cost elements. Int J Proj Manag, kidlington, v. 23, p. 275-282, 2005. 